\title{
Reorganization of Secondary and Tertiary Health Care Levels: Impact on the Outcomes of Oral Cancer Screening in the São Paulo State, Brazil
}

\author{
Fernanda Campos Sousa de ALMEIDA ${ }^{1}$ \\ Claudia CAZAL ${ }^{2}$ \\ Gilberto Alfredo PUCCA JÚNIOR ${ }^{3}$ \\ Dorival Pedroso da SILVA ${ }^{4}$ \\ Antonio Carlos FRIAS 5 \\ Maria Ercilia de ARAÚJO 5
}

\author{
${ }^{1}$ Biodentistry Program, UNIB - Ibirapuera University, São Paulo, SP, Brazil \\ ${ }^{2}$ Department of Clinical and Community Dentistry, Dental School, \\ UFPB - Federal University of Paraíba, João Pessoa, PB, Brazil \\ ${ }^{3}$ Department of Dentistry, UEM - State University of Maringá, Maringá, PR, Brazil; and Ministry of Health, Brazil \\ ${ }^{4}$ Department of Maxillofacial Prosthodontics, Dental School, USP - University of São Paulo, São Paulo, SP, Brazil \\ ${ }^{5}$ Department of Community Dentistry, Dental School, USP - University of São Paulo, São Paulo, SP, Brazil
}

\begin{abstract}
This study presents the strategies for prevention and early detection of oral cancer by means of screening in the elderly population of São Paulo, the richest and the most populous state of Brazil. This research was a retrospective longitudinal study based on the analysis of secondary data. The variables - number of participating cities, coverage of screening, and number of suspicious and confirmed cases of oral cancer - were divided into two periods: 2001-2004 and 2005-2008. Data were analyzed statistically by the chi-square test at $5 \%$ significance level. The implementation of a nationwide public oral health policy in 2004 and the reorganization of the secondary and tertiary health care were evaluated as mediator factors able to interfere in the achieved outcomes. From 2001 to 2008, 2,229,273 oral examinations were performed. There was an addition of 205 participating cities by the end of the studied period ( $\mathrm{p}<0.0001)$. The coverage of oral cancer screening increased from $4.1 \%$ to $16 \%(\mathrm{p}<0.0001)$. There was a decrease in the number of suspicious lesions (from $9 \%$ in 2005 to $5 \%$ in 2008) ( $<<0.0001$ ) and in the rate of confirmed oral cancer cases per 100,000 examinations (from 20.89 in 2001 to 10.40 in 2008) ( $<<0.0001)$. After 8 years of screening, there was a decrease in the number of suspicious lesions and confirmed cases of oral cancer in the population. The reorganization of secondary and tertiary health care levels of oral care seems to have contributed to modify these numbers, having a positive impact on the outcomes of oral cancer screening in the São Paulo State.
\end{abstract}

Key Words: oral neoplasms, public health, public policy, campaign, screening.

\section{INTRODUCTION}

After H1N1 influenza pandemic, the media, scientific community and general population turned their eyes to an ordinary disease and public policies were implemented to restrain its possible complications in high-risks groups $(1,2)$. In Brazil, a nationwide governmental mobilization (primary health care level) has been organized since 1999 in the form of a 15-day campaign in which all elderly individuals aged 60 years and older are invited to attend the basic health units for influenza immunization. Later, this 15-day campaign was thought to be an appropriated moment for monitoring this population with regard to their health and the increased risk of developing degenerative diseases. Since 2001, the São Paulo State Secretariat of Health has coordinated a screening for oral cancer by oral clinical examination, which occurs simultaneously with the influenza immunization of the elderly population. Oral screening has demonstrated a reduction in the mortality

Correspondence: Prof. Dra. Maria Ercilia de Araújo and/or Dra. Fernanda Campos S. de Almeida, Departamento de Odontologia Social, Faculdade de Odontologia, USP, Avenida Prof. Lineu Prestes, 2227, Cidade Universitária, 05508-000 São Paulo, SP, Brasil. Tel: +55-11-3091-7878. e-mail: mercilia@usp.br/fernandacsa@usp.br 
rate in high-risk oral cancer individuals (3).

After 8 years of monitoring of the elderly population of São Paulo State through the campaigns, and considering the major changes occurred in the setting of public oral health policies, it seems advisable to evaluate critically the official data of the applied screening program. It is the moment to propose solutions and revise strategies from the perspective of the nationwide oral health care network in order to contribute with an academic discussion, and perhaps cooperate in the dissemination of similar programs in other regions and countries. Therefore, the aim of this study was to examine the outcomes obtained during 8 years of campaign for oral cancer prevention and early detection in the Brazilian Sate of São Paulo, and to confront data recorded before and after the implantation of a national oral health policy in 2004 .

\section{MATERIAL AND METHODS}

This was a retrospective and longitudinal study based on the analysis of secondary official data disclosed by the São Paulo State government (4-7). During 8 years (2001-2008), oral examinations were performed in the elderly population during the annual public and free campaign for influenza vaccination. The examinations were carried out by dentists from the public health service using wooden spatulas and under natural light.

The variables 'number of participating cities', 'coverage of screening', 'number of suspicious lesions' and 'number of confirmed cases of oral cancer' were recorded and divided into two periods: 2001-2004 and 2005-2008. Data were analyzed statistically by the chisquare test at a significance level of 5\%.

The implementation of a national public oral health policy and the reorganization of the secondary and tertiary health care networks were evaluated as possible mediator factors able to interfere in the results.
The obtained data were compared before and after establishment of the CEO (specialized dental clinics) and CACON (Oncology Care Centers) in 2004.

\section{RESULTS}

Along 8 years of campaign, 2,229,273 oral examinations were performed with an average of 278,559 examinations per year (Table 1). By 2008, other 205 cities had joined the campaign, totalizing 539 (83.5\%) of the 645 cities of São Paulo State. This adherence rate to the campaign is significantly higher than that observed in $2004(51.8 \%)(\mathrm{p}<0.0001)$.

In 2001 , only $4.1 \%$ of vaccinated elderly were examined for oral cancer, while in 2008 this percentage increased to $16 \%$ (chi-square, $\mathrm{p}<0.0001$ ).

In 2001 , only $7.8 \%$ of examined elderly presented soft tissue alterations. This percentage reached its peak in 2002, with $9.7 \%$ of detected lesions. Starting in 2005, a gradual decrease occurred and the lowest percentage of soft tissue lesions were detected in 2008 (5.0\%). The increase of diagnostic tests conducted in 2001 compared with 2004, and the decrease in the number suspicious cases from 2005 to 2008 (Table 1) were statistically significant $(\mathrm{p}<0.0001)$.

Table 2 presents the reduction of positive cases of oral cancer between 2005 and 2008. The number of confirmed malignancies varied from 20.89 to $10.40 \mathrm{per}$ 100,000 examined elderly $(\mathrm{p}<0.0001)$.

\section{DISCUSSION}

The São Paulo state is the richest and the most populous in Brazil and has 645 cities distributed in an area of $248,209.23 \mathrm{~km}^{2}$. Its extension represents a challenge to joint public actions to the prevention of diseases. The implementation of oral cancer screening together a another kind of public heath campaign was

Table 1. Descriptive data of oral cancer screening in the São Paulo State, Brazil.

\begin{tabular}{lcccccccc}
\hline Year & 2001 & 2002 & 2003 & 2004 & 2005 & 2006 & 2007 & 2008 \\
\hline Number of cities & 334 & 443 & 512 & 490 & 317 & 509 & 503 & 539 \\
Number of examinations & 90,886 & 142,774 & 226,54 & 238,087 & 253,648 & 360,76 & 435,971 & 480,607 \\
Screening coverage (\%) & 4.1 & 6.4 & 8.8 & 8.7 & 10.8 & 12 & 15 & 16 \\
Suspicious soft tissue & 7,028 & 13,801 & 18,059 & 20,270 & 22,939 & 30,481 & 34,346 & 24,280 \\
lesions [n(\%)] & $(7.80 \%)$ & $(9.70 \%)$ & $(8.0 \%)$ & $(8.50 \%)$ & $(9.0 \%)$ & $(8.40 \%)$ & $(7.90 \%)$ & $(5.0 \%)$ \\
\hline
\end{tabular}

Source: Ministry of Health, São Paulo State Secretariat of Health and Cancer Foundation of São Paulo. 
hard and demanded persistence, but was worthy. A significant increase in the number of engaged cities and a gradual increase in the number of examined elderly were observed after a periodical 8 years of campaigns.

The campaign for prevention and early diagnosis of oral cancer aimed to insert educational and preventive activities related to oral cancer in São Paulo State. It was an pioneering initiative in Brazil and is still undergoing adjustments over the years, as seen by the adherence of new 205 cities to the campaign ( $p<0.0001)$. International literature $(8,9)$ indicates that, despite the recognized advances experienced so far, it remains a daily challenge dealing with complex structural problems in public health, which, in most cases, require different levels of governmental public interventions, multiple professional skills and varied levels of information. In these changing scenarios, the implementation and evaluation of social policies/programs have gained greater complexities and cannot be considered as ordinary instruments (or "kits") that can be applicable indistinctly to any kind of social context $(8,9)$.

At this point, for a better understanding of the presented data, it is important to elucidate how the Brazilian public health system is organized. Since 1988, the Federal Constitution guarantees free health care access to the entire population. Thus, it is considered a universal system that ensures, for example, influenza vaccination coverage for all elderly in Brazil. The state may propose actions and guidelines, but the cities can adhere or not to the proposed programs on a voluntary basis, respecting the principle of decentralization of the system (10). It is necessary an effort from the state managers to articulate and convince the cities to engage the programs on timely basis. As a result, the goals can only be observed after a certain period of time, and for that reason, the present research adequately examined the results after the period of 8 years.

The campaign for prevention and early detection of oral cancer was strategically combined with the national campaign for influenza vaccination because the highest incidence of oral cancer is between the fourth and fifth decades of life (11). Additionally, the Brazilian incidence of oral cancer in the elderly population over 60 years reaches $40 \%$ of all positive cases (12), which justifies an action of this magnitude in the country (13). Screening for degenerative diseases, mainly those related to smoking habits, in the elderly population is of great importance (14).

Furthermore, actions of this magnitude created a singular opportunity for oral health teams examine elderly individuals who tend to believe that oral examination are unnecessary because they usually are completely edentulous. The last database from epidemiological survey on Brazilian oral health showed that $64 \%$ of elderly people between 65 and 74 years old were completely edentulous (15).

Afact that has a decisive impact on the prognosis of the patient refers to the delay of about 4.5 months on average between the patient's first perception of oral lesions and

Source: Cancer Foundation of São Paulo.

Table 3. Criteria and codes used to identify the oral soft tissues aspect at the time of examination. Codes 1 and 2 refer to secondary level of health care.

\begin{tabular}{lcc}
\hline Classification & Codes & Criteria \\
\hline Low risk & 0 & Healthy oral soft tissues \\
High risk & 1 & Altered oral soft tissues without malignant aspect (alterations not listed in code 2) \\
$\begin{array}{l}\text { Patient re-examined by a } \\
\text { specialist of the secondary } \\
\text { oral health care level from } \\
\text { the same district }\end{array}$ & 2 & $\begin{array}{c}\text { Altered oral soft tissues with malignant aspect: }>14 \text { days of evolution of painless ulcers, } \\
\text { ulcers with endured or elevated boundaries, white lesions (leukoplakia) or pigmented } \\
\text { lesions; 14 days evolution of reddish lesions with well-defined borders suggesting } \\
\text { erytroleukoplakias; vegetative lesions with significant growth rate (papules, nodes, } \\
\text { granulated verrucous or ulcerated surfaces) }\end{array}$ \\
\hline
\end{tabular}


the first consultation with a physician or dentist in order to investigate the complaints (13). A recent study (16) pointed that cancer survivors presented a significant decrement for the overall and domain-specific quality of life ratings at 1 -year follow-up. Therefore, the screening performed in an asymptomatic population might be more relevant on patient's prognosis and quality of life (16).

In the present study, recording of oral soft tissue lesions was based on a specific classification developed by the São Paulo State Secretariat of Health (Table 3). Traditionally, it allows dentists who are not used to perform oral diagnosis for their everyday work to undertake patient categorization without major difficulties, and to select those cases that need a more specialized attention.

All cases of soft tissue lesions (Table 2) were later re-examined by a specialist of the secondary health care level from the same district in order to avoid detachment of the elderly or the lost of the follow-up of those cases. It increased the resolution of the campaign and avoided the losses observed by Antunes in 2004 (17). Moreover, since 2008, the Cancer Foundation of São Paulo State tracks all positive cases of oral cancer through its own cancer registry, and the 37 positive cases detected in 2008 were treated and properly monitored in public hospitals (5).

In this study, it was interesting to register a decrease of new cases of oral cancer and suspicious lesions among the elderly over the years $(p<0.0001)$. It could be seen that, by 2004, the campaign was structured with the gradual adherence of new cities and, later, by reorganizing the system of reference and counter-reference for both diagnosis and treatment. In the initial period of the campaign (2001-2004), there was an increase in the incidence of suspicious cases occurred, which is probably explained by the enclosed demand until that historic moment. Moreover, there was a lack of access to public medical care services and also a lack of structure for reference and counter-reference for the detected cases.

The second period (2005-2008) of the campaign showed a reduction of both rates of confirmed cases and suspicious lesions. This period coincided with the implementation of a new national policy for oral health care (18), the secondary oral health care network, and the CEOs. Still, it was in 2005 that the Cancer Foundation of São Paulo State started a much more direct and effective dialog with the tertiary health care network and the CACONs, which were responsible for oral cancer treatment of the cases from the secondary health care network.

The design of the current campaign seems to be effective, as it was able to maintain a specific population under control, starting with those individuals who complete 60 years of age every year. The increasing number of detected suspicious lesions might be explained by the deficient access to public dental services or may be indicative of inefficient solvability of the secondary and tertiary health care levels by the years 2004 and 2005 .

After 2004, when the CEOs were implemented through federal government financial incentive (19), there were an increasing availability of skilled professionals in the field of oral diagnosis, which enable to respond more adequately to the identified demands. The following reduction of suspicious lesions and confirmed cases of oral cancer may be attributed to the saturation of the sample and equally to the improvement of the patients' access to secondary and tertiary levels of oral health service care.

Finally, in 2010, Pereira-Torres (20) published an important analysis of the impact of public policies on data on oral cancer and concluded that from a strict scientific standpoint, there is no evidence to support the claim that any public intervention might have a quantitative impact on oral cancer incidence and morbidity other than tobacco and alcohol consumption control. These factors should be regarded as major targets for public policies aimed to impact positively the cases of oral cancer. Moreover, there seems to be a low recognition that reducing inequalities could decrease oral cancer numbers. Government, research community and clinical dentists should combine efforts in order to demand and produce more consistent scientific evidence of impact when evaluating or proposing oral cancer public policies.

It is expect that the present results could contribute to the debate about the importance of public policies in oral health because we are convinced that they are fundamental to the organization of services and demand for improvement of the indices and indicators in health.

Concomitant oral cancer prevention campaign and influenza vaccination campaign has been proven quite effective in the reduction of suspicious lesions and confirmed cases of oral cancer. Apparently, the saturation of the sample, implementation of a national oral health policy, the establishment of a more efficient secondary oral health care level, and a greater involvement of the tertiary network services for oral oncology care, might explain the gradual decrease of suspicious lesions and 
new cases of oral cancer among the screened population. The campaign model used in the state of São Paulo have shown that the involvement of all levels of health care can be efficient if well articulated and undertaken in compliance with the federal government public policies, producing successful efforts in the prevention and early detection of oral cancer.

\section{RESUMO}

Este estudo teve como objetivo apresentar as estratégias de prevenção e detecção precoce de câncer bucal, através de triagem (rastreamento) na população idosa do Estado de São Paulo. Esta pesquisa foi um estudo longitudinal retrospectivo baseado na análise de dados secundários. As variáveis - número de cidades participantes, a cobertura da triagem e o número de casos suspeitos e confirmados de câncer bucal - foram divididos em 2 períodos (2001-2004 e 2005-2008). As variáveis foram testadas através do teste do qui-quadrado. A implantação da política nacional de saúde bucal, em 2004, foi incluída como variável capaz de interferir nos resultados alcançados. De 2001 a 2008, 2.229.273 exames foram realizados. Foi observado um aumento de 205 cidades participantes até o final do período estudado $(p<0,0001)$. A extensão do rastreamento para o câncer de boca aumentaram de $4,1 \%$ para $16 \%(\mathrm{p}<0,0001)$. Houve uma diminuição no número de lesões suspeitas (de 9\% em 2005 para 5\% em 2008) (p<0,0001) e na taxa de casos confirmados de câncer bucal por $100.000(20,89$ em 2001 e 10,40 em 2008) ( $p=0,0003)$. Após 8 anos de triagem, observamos uma diminuição no número de lesões suspeitas e casos confirmados de câncer bucal entre os voluntários. É possível que a reorganização dos níveis secundário e terciário de cuidados bucais ajudou na modificação desses números.

\section{REFERENCES}

1. OMS. Experts advise WHO on pandemic vaccine policies and strategies. 2009. Available from: http://www.who.int/csr/disease/ swineflu/notes/briefing_20091030/en/index.html [Latest access: May 2012].

2. Thompson WW, Shay DK, Weintraub E, Brammer L, Cox NJ, Fukuda K. Influenza vaccination among the elderly in the United States. Arch Intern Med 2005;165:2038-2039.

3. Sankaranarayanan R, Ramadas K, Thomas G, Muwonge R, Thara $\mathrm{S}$, Mathew B, et al.. Effect of screening on oral cancer mortality in Kerala, India: a cluster-randomized controlled trial. Lancet 2005;356:1927-1933.

4. São Paulo State, Secretariat of Health, Health Planing Coordination, Oral Health Technical Center. Prevention and early diagnosis of oral cancer [final report]. Impact project: oral examination and educational actions between April 24 and May 5, 2001 - vaccination of elderly population. Project oral examination and educational actions during the elderly vaccination campaign, in April 2002 - version 2002. São Paulo State: Secretariat of Health; 2002.

5. São Paulo State Cancer Foundation. Reports of the oral cancer prevention campaign - 2005/2008. São Paulo (SP), 2008. Available from: http://www.fosp.saude.sp.gov.br/ [Latest access: May 2012].
6. São Paulo State Secretariat of Health. Coordination of Health Planning - Technician Center of Dental Health. Prevention and early diagnosis of oral cancer: final report. São Paulo (SP), 2003. Available from: http://portal.saude.sp.gov.br/resources/ ses/perfil/profissional-da-saude/grupo-tecnico-de-acoesestrategicasgtae/saudebucal/artigoseteses/estudoseidemiologicos/ estudosepidemiologicos/ prevencao_e_diagnostico_do_cancer_ bucal_-_2003.pdf [Latest access: May 2012].

7. São Paulo State Secretariat of Health. Coordination of Health Planning - Technician Center of Dental Health. Prevention and early diagnosis of oral cancer: final report. São Paulo (SP), 2004. Available from: http://portal.saude. sp.gov.br/resources/ses/perfil/profissional-da-saude/grupotecnico-de-acoes-estrategicasgtae/saudebucal/ artigoseteses/ estudosepidemiologicos/estudosepidemiologicos/ prevencao_e_ diagnostico_do_cancer_bucal_-_2004.pdf [Latest access: May 2012].

8. Magalhães BRR. Evaluation of initiatives and programs across sectors in health: challenges and learnings. Bull World Health Organ 2009; 14:861-868.

9. Weiss C. Nothing as practical theory of the good: exploring theory-based evaluation for comprehensive community initiatives for children and family. In: JP Connell, AC Kubisch, LB Schorr, $\mathrm{CH}$ Weiss, editors. New Approaches to Evaluating Community Initiatives. Washington, D.C.: Aspen Institute, 1995. p. 65-93.

10. Collins C, Araujo J, Barbosa J. Decentralising the health sector: issues in Brazil Health Policy. 2000;52:113-127.

11. Cornwall A, Shankland A. Engaging citizens: lessons from building Brazil's national health system. Soc Sci Med 2008;66:2173-2184.

12. Perussi MM, Denardin VOP, Fava AS, Rapoport A. Oral squamous cell carcinoma in the elderly in São Paulo. Rev Assoc Med Bras 2002;48:341-344.

13. Scott SE, Grunfeld EA, McGurk M. Idiosyncratic relationship between diagnostic delay and stage of oral squamous cell carcinoma. Oral Oncol 2005;41:396-403.

14. Spalding MC, Sebesta SC. Geriatric screening and preventive care. Am Fam Physician 2008;78:206-215.

15. São Paulo. Oral health status in São Paulo in 2002: Final Report. Available from: http://portal.saude.sp.gov.br/resources/gestor/ destaques/saude_bucal/condicoes_de_saude_bucal, 2002.pdf [Latest access: May 2012].

16. Biazevic MGH, Antunes JLP, Togni J, Andrade FP, Carvalho MB, Wünsch-Filho V. Survival and quality of life of patients with oral and oropharyngeal cancer at 1-year follow-up of tumor resection. J Appl Oral Sci 2010;18:279-284.

17. Antunes JLF, Toporcov TN, Wünsch-Filho V. The effectiveness of the oral cancer prevention and early diagnosis program in São Paulo, Brazil. Rev Panam Salud Publica 2007;21:30-36.

18. INCA. Estimative 2010. Incidence of cancer - Brazil. Rio de Janeiro, 2009. Available from: http://www2.inca.gov.br/wps/ wcm/connect/inca/portal/home [Latest access: May 2012].

19. Brazil. Ministry of Health. Secretary of Health Assistance. Department of Primary Health Care. Monitoring and Evaluation Coordination. Evaluation of Primary Health. National Policy on Oral Health. Brasilia, Ministry of Health, 2004.

20. Torres-Pereira C. Oral cancer public policies: is there any evidence of impact? Braz Oral Res 2010;37-42.

Received July 17, 2011 Accepted January 13, 2012 